\title{
Dictynna
}

Dictynna

Revue de poétique latine

13 | 2016

Varia

Did Somebody Say Augustan Totalitarianism?

Duncan Kennedy's 'Reflections,' Hannah Arendt's

Origins, and the Continental Divide over Virgil's Aeneid

\section{Elena Giusti}

\section{OpenEdition}

\section{Journals}

Electronic version

URL: http://journals.openedition.org/dictynna/1282

DOI: 10.4000/dictynna.1282

ISSN: 1765-3142

Electronic reference

Elena Giusti, « Did Somebody Say Augustan Totalitarianism? Duncan Kennedy's 'Reflections,' Hannah Arendt's Origins, and the Continental Divide over Virgil's Aeneid », Dictynna [Online], 13 | 2016, Online since 20 December 2016, connection on 10 September 2020. URL : http://journals.openedition.org/ dictynna/1282 ; DOI : https://doi.org/10.4000/dictynna.1282

This text was automatically generated on 10 September 2020.

Les contenus des la revue Dictynna sont mis à disposition selon les termes de la Licence Creative Commons Attribution - Pas d'Utilisation Commerciale - Pas de Modification 4.0 International. 


\title{
Did Somebody Say Augustan Totalitarianism? Duncan Kennedy's 'Reflections,' Hannah Arendt's Origins, and the Continental Divide over Virgil's Aeneid
}

\author{
Elena Giusti
}

1 In 1992, the long and static continental divide between the so-called 'Harvard' and 'European' schools, which debated the Augustanism and anti-Augustanism of Augustan texts, and in particular of Virgil's Aeneid, was sealed by Duncan Kennedy's influential essay "“Augustan" and "anti-Augustan": Reflections on terms of reference'. In this essay, Kennedy provided a mind-blowing dialectical deconstruction of the old polarity, which ended up being more successful than contemporary Augustan literary critics could foretell: notwithstanding the predictions of scholars such as Alessandro Barchiesi, ${ }^{1}$ the debate demonstrated that it had less of a future than even Kennedy allowed. In the field of Virgilian studies, 'Reflections on Terms of Reference' soon became - and indeed it still is - the article that all Virgilians would reference, rather than engage with, in order to demonstrate the fruitlessness of the old diatribe and to unleash Virgilian studies free to investigate new shores. 'Anti-Augustan,' as a term, was implicitly and subconsciously banned; with a few exceptions, the whole debate became unfashionable, the questions it had raised were deemed unproductive and sterile. ${ }^{2}$

2 The present article aims to offer further reflections on Kennedy 1992's 'Reflections' and their reception, in order to demonstrate that while most scholarship interpreted the essay in relation to reader reception criticism, Kennedy 1992 is in fact in direct dialogue with ideology critique and with academic and non-academic writings on the ideological language of $20^{\text {th }}$ century totalitarianism, a recognition which opens the door for different applications of the piece to the field of Augustan literature and ideology, and thus for different interpretations of Virgil's text. In what follows, we shall first 
recapitulate the arguments proposed by Kennedy 1992 and analyse some instances of its scholarly reception, before comparing its findings to what is arguably the most influential work on totalitarianism in the $20^{\text {th }}$ century, Hannah Arendt's The Origins of Totalitarianism (1951). A joint reading of the two, I shall argue, opens up new possibilities for the interpretation of Augustan literature, challenging our understanding of Augustan ideology in Virgil's Aeneid, a text which is arguably creator, no less than creation, of the ideology itself.

\section{Kennedy's dialectic twist: could this really be the end?}

3 While scholars still debated whether Virgil's 'further voices's implied the poet's antiAugustan subversion of, and resistance to, the same Augustan ideology that the Aeneid nonetheless participated in shaping, Duncan Kennedy's major insight took root at the level of language and dialectic. The use of the terms 'Augustan' and 'anti-Augustan,' Kennedy posited, betrays a distinction that only makes sense for those who believe in a static view of language, which 'attempts to set up categories as distinct and autonomous' $^{4}$ and 'seek[s] an ultimate validity for [its] answers in intentionalism,' ${ }^{5}$ producing a 'type of explanation which is author-centred, individualist, and which suppresses the social dimension of the discourse'. ${ }^{6}$ To such a view, Kennedy opposed:

the dynamic, discursive view... [which] sees words as the momentary intersection of a host of discourses (open-ended, conflicting, and even contradictory), stressing the difference within words, their discontinuities, and their capacity to change their meanings.

(Kennedy 1992: 40)

As a consequence,

...what as abstracts are logically opposite by the process of definition which sets them off against each other can co-exist within discourse without contradiction, as "war" (its meaning ideologically determined) and "peace" (its meaning also ideologically determined) do in the ideology which generated the power and position of Augustus.

(Kennedy 1992: 40)

5 According to the dialectic inscribed in this view, every word of the 'establishment discourse' has inscribed within it 'the potentiality for subversion, ${ }^{7}$ and therefore becomes liable to coexist with its opposite, so much so that the term 'Augustan' always already implies and even necessitates its own subversion, or inversion: just as the Greek anti means both 'opposite' and 'instead, in the place of' (often denoting equivalence, such as 'as much as,' 'as good as'), the term 'anti-Augustan' changes its meaning from 'against Augustan' to 'in the place of Augustan,' or even 'equal to Augustan.' It turns from antagonist into accomplice, with anti- being left out as a misrepresentative prefix, which only reinforces the all-encompassing nature of the ideological abstract: (anti-)Augustan-ism.

Kennedy's contribution still makes it difficult for Virgilians to approach the old debate in a profitable way. On the one hand, it has become generally agreed that the 'further voices' of Virgil or Ovid must be unhooked from a binary opposition and re-inscribed within an ideological discourse in which many voices can coexist in their openendedness and apparent contradictions; on the other hand, the essay, much against its own aims, seems to have inadvertently contributed to a more or less tacit suppression 
of the term 'anti-Augustan' altogether rather than stimulating further reflections on its shifting meaning. In Virgilian studies, Kennedy 1992 is most often referenced, when referenced, as an excuse for disregarding the debate, with little or no attempt at actual engagement. A few exceptions, such as Martindale's 1993 essay 'Descent into Hell. Reading Ambiguity, or Virgil and the Critics' and Thomas's 2001 monograph Virgil and the Augustan Reception, use Kennedy 1992 in order to shift the focus from Virgil to Augustus and Augustanism, or rather to the idea of 'Augustus' and 'Augustanism,' and to the infinite ways that the shifting discourse of Augustan ideology can be (re-)appropriated in readers' reception. ${ }^{9}$ This reception of Kennedy 1992 in terms of reader-response criticism has been so influential that the piece is sometimes referenced together with Alison Sharrock's 1994 article 'Ovid and the politics of reading, ${ }^{10}$ even though Sharrock 1994 can actually be recognised as the first attempt to respond to Kennedy precisely by using reader-response criticism as a means to validate the anti-Augustanism of Ovid's Ars Amatoria. 'A text of itself,' writes Sharrock in a quotation often referenced together with Kennedy, "cannot be either "pro-" or "anti-" "Augustan," only readings can be'. ${ }^{11}$ But this should not lead us necessarily into an aporetic strategy, since, she writes, 'if everyone who responded to it [i.e. the Ars] read it as subversive... then it seems to me to stretch the credible bounds of the authority of intention to claim that the text is not anti-Augustan' ${ }^{12}$ Her conclusion, however, concedes to Kennedy that even if we allow this anti-Augustan reading, the act of undermining Augustan authority necessarily accords that authority and so legitimises it. $^{13}$

7 Sharrock 1994 is one of the very few contributions that recognise these two partially distinct strands of Kennedy 1992: reader-response criticism and ideology critique. But Sharrock also opens the door for the Ovidians' reactions to Kennedy, which strikingly counterpoise the silence of the Virgilians. This is due in part to the fact that Kennedy 1992, although it clearly means to respond to the Virgilian debate, chose instead Horace's Satires and Ovid's Ars and Fasti as examples for the old polarity's dissolution. But it is also true that some of the anti-Augustan readings of Ovid only succeed if they are simultaneously accompanied by Augustan readings of Virgil - notably by Ovid himself. This is the case with Sharrock's interpretation of Ovid's mockery of the Georgics in the Ars, ${ }^{14}$ or of Barchiesi's reading of Numa in the Fasti as set in opposition to Aeneid 6, and thus, incidentally, to the Prince himself. ${ }^{15}$ Perhaps paradoxically, the Ovidian anti-Augustan reactions to Kennedy can be seen to do a disservice rather than a service to the so-called Harvard School of Virgilian studies.

If we home in on these Ovidian reactions, we see, on the anti-Augustan side, Sergio Casali, Anthony Boyle and especially Peter Davis ${ }^{16}$ on the Augustan - or rather Kennedian - side, Alessandro Barchiesi, Ellen O'Gorman, Thomas Habinek and Philip Hardie. This 'Kennedian' side is pretty varied: on the one hand, in 1997, Ellen O'Gorman, much like Alison Sharrock, 'take[s] the point that the term "oppositional" itself sustains the domination which it purports to examine, ${ }^{17}$ and Philip Hardie's formulation of an 'ineluctable collusion between artist and ruler'18 would become quite influential among Augustan scholars; on the other hand, Barchiesi's The Poet and The Prince shows concern over aporetic outcomes, and scepticism throughout toward the possibility of expressing arguments without preconceived judgments, ${ }^{19} \mathrm{a}$ risk that Thomas Habinek avoids by confessing from the start his anti-Galinskian preference for the 'bleaker aspects' of the Augustan age when using Kennedy 1992 to show that 'an 
important task of the critic is to bring out the contradictory aspects of power that a given text seeks to suppress'. ${ }^{20}$

9 Among the anti-Augustan Ovidians, one must single out the work of Peter Davis, whose anti-Kennedian obsession with Kennedy 1992 could eventually be seen to help legitimise, rather than undermine, the authority of Kennedy's essay. Davis devotes the whole first chapter of Ovid and Augustus, a reworking of his 1999 article, to a refutation of Kennedy. It seems to me, however, that Davis and Kennedy speak two different languages, ${ }^{21}$ attributing different 'meanings' to 'meaning,' when Davis presents Kennedy's argument with the lapidary statement that 'for Kennedy, it seems, the terms "pro-Augustan" and "anti-Augustan" are essentially meaningless'. ${ }^{22}$ Davis argues that, even if we allow an anti-Augustan reading of the most Augustan text of all, the Res Gestae, this does not mean that the Augustan and anti-Augustan interests are not 'identifiable and distinct': 'does anyone really believe,' he asks, 'that the Res Gestae can usefully be labelled "anti-Augustan"?'. ${ }^{23}$ As much as he refrains from it, Davis's focus on 'interests' here clearly calls for authorial agency and intentionality, and does not discuss the ideological establishment discourse, and the fact that it is shaped in such a way as to incorporate and therefore prevent the opposite interests. It seems to me that the cause of this misunderstanding must be sought in the reception of Kennedy 1992 as a piece of reader-reception criticism rather than ideology critique. This is clear from Davis' labelling of Kennedy's view 'not as up-to-date "reception criticism" but as oldfashioned subjectivism ${ }^{24}$ when reacting to Kennedy's dissolution of the polarity within a dynamic framework, which is perhaps the most famous passage of the essay:

no statement (not even made by Augustus himself) can be categorically "Augustan" or "anti-Augustan"; the traces of its constituent discourses were - and still are open to appropriation in the opposite interest. The degree to which a voice is heard as conflicting or supportive is a function of the audience's - or critic's - ideology, a function, therefore, of reception. Power is successful in so far as it manages not so much to silence or suppress as to determine the consumption of the oppositional voice within its discourse.

(Kennedy 1992: 40)

Davis reads this passage as inherently contradictory: how can Kennedy claim that it is the reader's ideology that determines the reaction to the text and at the same time say that it is for the text to determine that very same reaction? ${ }^{25}$

\section{Kennedy's 'Reflections' and Augustan Totalitarianism}

11 The question that Davis justly poses may be answered, I submit, by recognising that Kennedy 1992 displays, consciously or subconsciously, a clear influence from works of fiction and perhaps academic writings on the ideological language of totalitarianism. If we analyse the essay under this lens, it is possible to flip it over and make it sustain a totalising, if not totalitarian, view of Augustanism - which would turn the essay itself into an arguably 'anti-Augustan' piece. Since the power of totalitarian ideologies lies in their ability to incorporate the voice of dissent within the voice of consent, the practice of unmasking their inner workings to lay bare their artificial structure is the only weapon left with which to oppose them: if we read Kennedy 1992 in this way, it can actually be used to sustain anti-Augustan readings in a way which is peculiarly different from the Harvard School, but can still count as oppositional. 

'peace' in Augustan ideology. ${ }^{26}$ In this passage, Kennedy is explicitly indebted to a 1985 essay by Erich Gruen, 'Augustus and the Ideology of War and Peace,' in which Gruen argues how Augustus 'did not so much celebrate peace as the means of its accomplishment,' as in the Res Gestae's parta uictoriis pax (RG 14), in which Augustus 'pronounced no pacifist creed but declared a warrior's achievement. ${ }^{27}$ In the same piece, Gruen also interprets the outside panels of the Ara Pacis in a double set of oppositions: Aeneas performing a sacrifice to the Penates is balanced by a partially preserved Mars, while the unidentified female deity 'calling attention to the blessings of a tranquil time' has her opposite in the very fragmentary panel of Roma seating on a pile of arms. 'The imagery,' Gruen argues, 'takes on meaning in combination. The accomplishment of peace is inseparable from success in war. ${ }^{28}$

this reading of Augustan ideology as a combination of revolution and evolution, with the Republican, anti-Augustan side, already inscribed within both the Res Gestae and the Ara Pacis, was in the air when Kennedy wrote. Only one year before Kennedy, and with no reference to Gruen, Jás Elsner provided a similar interpretation of the internal frieze of the Ara Pacis:

The fruitful bliss of the Italia scene, cow and all, is insured by the procession of cows to their death at this very altar, by the cows becoming the skulls from which the garlands hang. The visual pun works in both Latin and English: the garlands depend on the skulls. The cow, a recurring image in its different forms in the precinct, is a visual metaphor for the reciprocity of sacrifice, for what depends on what and for the cost of Augustan plenty. The scene of Italia could not be there but for this altar, could have no meaning but for the skulls.

(Elsner 1991: 58)

14 After comparing this imagery to the blood imagery and slaughter present in Horace's Carmen Saeculare (lines 49-52), Elsner comes to the conclusion that:

the image of blood - which echoes in the references to war and sacrificial slaughter - is transferred to the Princeps upon whom the success of these acts depends. To be Augustus is an act of blood (in both the kin and carnage senses of the word) and upon the Augustan blood of divine progeniture, war, and sacrifice rests the golden age of Augustan plenty...

(Elsner 1991: 59)

Therefore, reading the anti-Augustus chez Augustus is not peculiar to Kennedy, but it is only Kennedy who glosses Gruen's chapter with the memory of the lapidary statement 'War is Peace'. Which happens to be the first slogan of the party that Winston Smith sees inscribed on the white pyramidal building of the Ministry of Truth at the beginning of Orwell's Nineteen Eighty-Four, a work that would later prove especially influential in Kennedy's own work:29

The Ministry of Truth - Minitrue, in Newspeak... was startlingly different from any other object in sight. It was an enormous pyramidal structure of glittering white concrete, soaring up, terrace after terrace, 300 metres into the air. From where Winston stood it was just possible to read, picked out on its white face in elegant lettering, the three slogans of the Party:

WAR IS PEACE

FREEDOM IS SLAVERY

IGNORANCE IS STRENGTH

(George Orwell 1949, Nineteen Eighty-Four, Chapter 1) 
16 foreign war for that pacification, Kennedy 1992 takes it to mean that in the Augustan ideology even civil war, the main concern of Virgil's anti-Augustanism, can equal peace, that discordia can spell concordia. This perversion of language resonates with the totalitarian perversion of language as described by Orwell in the party's intention to make dissent simply unpronounceable in Newspeak. When we read Kennedy 1992 in the light not just of Orwell, but also of John Henderson's use of Romespeak to describe the language of the establishment discourse at Rome,${ }^{30}$ we can see the loaded antiAugustan connotations of the terms chosen by Kennedy in a sentence such as 'the power of Augustus was a collective invention... a complex network of dependency, repression, and fear'. ${ }^{31}$ When Kennedy claims that, in Horace's Satires, 'the word libertas... a term previously mobilised to support a non-monarchical system... changed direction to support an autocratic one, ${ }^{32}$ or that 'Ovid's ironic and flippant appropriation [i.e. of the Augustan programme]... helps to render [it] legitimate, ${ }^{33}$ he is also drawing attention to the poets' inability to express an oppositional statement except within a discourse that has rendered that opposition impossible to voice.

In short, Kennedy 1992 itself seems to attempt to mirror the ideology that it describes, inasmuch as it is used to sustain both (pro-) Augustan and anti-Augustan scholarship. The essay is in fact praised by Karl Galinsky as a piece to which his 1996 (pro-)Augustan monograph (Augustan Culture: An Interpretative Introduction) is much indebted, ${ }^{34}$ and Peter Davis does not hesitate to tar Galinsky and Kennedy with almost exactly the same brush. ${ }^{35}$ However, Kennedy 1992 is at the same time used by Thomas Habinek in an explicitly anti-Galinskian vein ${ }^{36}$ and one may well suspect that its indebtedness to Orwell is laid bare in John Henderson's review article of Galinsky's monograph, which emphasises the scholars' discovery of 'double-think involved in post-Actian discourse' ${ }^{37}$ as a means to overcome the stale bipolar options of the old continental debate.

\section{Arendt's Origins and Augustan Totalitarianism}

18 It is with this anti-ideological, and therefore anti-Augustan, reading of Kennedy 1992 in mind that I shall now turn to Hannah Arendt's writings on totalitarianism, not with the aim of establishing a direct relationship between Arendt's work and Kennedy's essay, but in order to assess how a joint analysis of the two can illuminate our understanding of Augustan ideology in general, as well as providing further reflections on the stale debate over Virgil's Aeneid in particular. There is, however, a double danger inherent in this practice. Firstly, since even the use of the term propaganda has often been argued to be anachronistic for the Augustan context,,$^{38}$ any association between the concept of totalitarianism and the Augustan regime may sound like a deliberate and unjustified anachronism, which it certainly is. Clearly the Augustan regime had nothing like the means of control and propaganda that we associate with the totalitarianisms of the $20^{\text {th }}$ century, and nor does it sound reasonable, let alone appealing, to coerce the complexities of Augustan poetry into the picture of a mere laboratory for the spreading of political messages. ${ }^{39}$ Moreover, it must be noted that even in contemporary practice the concept of totalitarianism is not conceived of as applicable outside its very limited field of action. Indeed, the scholarship on totalitarianism moves no less carefully than classical scholarship when using the term outside Hannah Arendt's limitation of the concept as inextricably tied to the unique experiences of $20^{\text {th }}$ century Nazi Germany

Dictynna, 13 | 2016 
and the Soviet regime. In Did Somebody Say Totalitarianism? (2011), Slavoj Žižek notes how the notion, as conceived by Arendt, 'far from being an effective theoretical concept, is a kind of stopgap: instead of enabling us to think, forcing us to acquire a new insight into the historical reality it describes, it relieves us of the duty to think, or even actively prevents us from thinking'. ${ }^{40}$ Here, Žižek's use of the concept as key for interpreting aspects of neo-liberal society is intentionally provocative, but it sheds light on the fact that some modalities of totalitarian language and propaganda actually survived the $20^{\text {th }}$ century, and that studies on their workings can still enlighten very different political systems from the ones that they originally purported to explain. ${ }^{41}$

To apply the notion of totalitarianism forwards, as Žižek does, undermines the concept of totalitarianism as set out by Arendt; but to apply it backwards, as I shall do below, goes even more explicitly against Arendt, who emphasises more than once in The Origins the difference between dictatorships, tyrannies, authoritarian rules and the totalitarianism of Hitler and Stalin, in which not even Mussolini's government completely partakes, as much as Italian fascism provided the origin of the term in the first place. ${ }^{42}$ Indeed, in The Origins, Arendt argues from the start for the unprecedented and unparalleled experience of totalitarianism. In the section on antisemitism as the first root of totalitarian rule, she points out how 'the rise of terror as a major weapon of government' works differently from other dictatorships and tyrannies, in so far as it is now used 'as an instrument to rule masses of people who are perfectly obedient,' striking victims who are 'innocent even from the point of view of the persecutor'. ${ }^{43}$ In the section on imperialism as the second root of totalitarian rule, she singles out 'expansion for expansion's sake' as an 'entirely new concept in the long history of political thought and action'. ${ }^{44}$ Finally, the section on totalitarianism emphasises the differences between the new principle of totalitarian domination and the old principle of authority: while 'authority is meant to restrict or limit freedom... totalitarian domination... aims at abolishing freedom, even at eliminating human spontaneity in general'. ${ }^{45}$

20 The differences between authoritarian, tyrannical and totalitarian governments are addressed not only in the section of The Origins devoted to totalitarianism, but even more thoroughly in the 1954 essay 'What is Authority?'. ${ }^{46}$ Here Arendt distinguishes the three systems by using three different representative models. While Orwell's Ministry of Truth had a pyramidal structure, the pyramid for Arendt is limited to authoritarian and tyrannical rules. This is because the source of authority lies outside the authoritarian government, and the seat of its power is located at the top. ${ }^{47}$ The Romans, as she later expounds in the essay, invented both authority and tradition, ${ }^{48}$ but their source of authority, in contrast to the Christian system, lay exclusively in the past, and thus the Roman model can be represented with a downward pyramid, which stretches into the depth of an earthly past rather than into the heights of the sky. ${ }^{49}$ The pyramid is also the model for tyrannical rule, but in this case one must imagine a pyramid in which all the intervening layers between top and bottom have been destroyed, so that the bottom is levelled, and the ruler remains suspended at the top, above anyone else. ${ }^{50}$ In contradistinction to these regimes, totalitarianism for Arendt is better represented by an onion, because the totalitarian leader does not act from the top of the structure, but from within the structure, and hierarchy is abolished in favour of a direct relationship between all strata of the structure and the leader, whose will can be embodied by anyone, 'everywhere and at all times': 
In contradistinction to both tyrannical and authoritarian regimes, the proper image of totalitarian rule and organization seems to me to be the structure of the onion, in whose center, in a kind of empty space, the leader is located; whatever he does whether he integrates the body politic as in an authoritarian hierarchy, or oppresses his subjects like a tyrant - he does it from within, and not from without or above... The great advantage of this system is that the movement provides for each of its layers, even under conditions of totalitarian rule, the fiction of a normal world along with a consciousness of being different from and more radical than it... (Arendt 1961 [or. 1954]: 99)

...between the supreme power (the Fuehrer) and the ruled there are no reliable intervening levels, each of which should receive its due share of authority and obedience. The will of the Fuehrer can be embodied everywhere and at all times, and he himself is not tied to any hierarchy, not even the one he might have established himself.

(Arendt 2004 [or. 1951]: 525)

21 Arendt's belief in the uniqueness of the $20^{\text {th }}$ century experience should not prevent us from applying her insights into the workings of totalitarian systems to different contexts as well. As much as she stresses the pyramidal structure of Roman authoritarianism, Arendt herself does not provide any clue as to how to reconcile this downward pyramid, in which authority is based and placed in the exemplary past, with a regime such as that of Augustus, who at the same time helped in shaping, choosing, and therefore re-creating and rewriting that past by inserting himself into every bit of it as its ultimate telos, ${ }^{51}$ and also presented his governmental system - both a continuation and a rupture from the Republic - through another of those contradictory coexistences of opposites encapsulated in the concept of primus inter pares. Even though Arendt herself would have objected to the suggestion, this concept seems to echo her symbolic rendering of totalitarian rule as the paradoxical system in which the leader's all-encompassing power depends on the fact that he is located both above and at anyone else's level. What is more, Arendt's insights remind us closely of Kennedy's interpretation of the all-encompassing nature of Augustanism, since Arendt argues that it is the performed and advertised equality of the leader that allows him to transcend those who nonetheless remain his 'subjects' and to transform himself into a concept, an ideology, which can be embodied and applied by anyone without the need for intermediaries. While tyrants are aloft and above their subjects, with whom they communicate through a repressive system of intermediate layers, the totalitarian leader instead represents himself as one - but the one - of his subjects. This is how he manages to permeate all strata of the population in an ultimately repressive way, but by temporarily maintaining the 'fiction of a normal world' in which oppositional voices are never explicitly silenced, but only recomposed in order to make them adhere to the new system. This is the totalising nature of Augustanism as expressed by Kennedy: the ultimate reason why it is impossible to track down dissent in terms of antiAugustanism. Indeed, we have already seen how Kennedy's notion that the regime is successful 'in so far as it manages not so much to silence or suppress as to determine the consumption of the oppositional voice within its discourse' ${ }^{52}$ resonates with the totalitarian perversion of language as described by Orwell in the party's intention to make dissent simply unpronounceable in Newspeak. This does not mean that one should stop wondering about the presence of such dissent in the Augustan texts, but rather that we must always be conscious of the fact that the Augustan revolution often makes the languages of dissent and consent appear indistinguishable. 
By adopting this perspective, we move our focus from the author, as well as from the reader, to the context, although the latter in turn is also partly a construction made both by the author and by ourselves as readers. To take as an example the never-ending debate over the interpretation of Virgilian ambiguity, ${ }^{53}$ we do not wonder whether ambiguities in Virgil may be a deliberate sign of his disallegiance to the regime, nor do we argue that their meaning is ultimately dependent on our unavoidably prejudiced reception of them. Rather, we take both their existence and the open-endedness of their interpretation as a sign not of the 'doublespeak' of the author, but of the 'doublethink' of the system, i.e. of the 'power [of the Augustan literary language] of holding two mutually contradictory beliefs... simultaneously, and accepting both of them'. ${ }^{54}$ This kind of doublethink implies no danger of subverting the current political order, because there exists no conceivable realistic option to that order, and therefore no correspondent language for conveying a desire for such unimaginable alternative. In the Aeneid, for instance, the continuous evocation of civil war can be thought to convey Virgil's 'further voice' of dissent and unmask the horrors on which the Augustan regime is founded, ${ }^{55}$ but it can also be reinscribed within the language of Augustan ideology and signify the very necessity and prerequisite for the founding of the Principate, which needed to 'destroy' the degenerate late Republic in order to start 'contructing' anew. ${ }^{56}$ Scholars interested in recovering Virgil's intention can therefore either argue that Virgil's reminder of the price to pay for the pax Augusta attempts to dismantle the optimistic vision that the ideology of the pax itself wanted to promote, or instead posit that Virgil's civil war echoes are deliberately juxtaposed with the optimistic vision of the present and future regime in order to magnify the achievement of pax. While the preference for one interpretation over the other is ultimately driven by our preconceived beliefs and interests, it is difficult, once we look at the context, to conceive how a poet born in $70 \mathrm{BCE}$ in a political system which had been in crisis since at least $133 \mathrm{BCE}$ could still conceive of republicanism as a realistic rather than idealistic political option. All the more so since the Augustan regime had anticipated the possible adoption, at the hands of its opponents, of the political and religious context that predated the crisis, by presenting itself as a restitution of the (middle) Republic and leaving its opponents as supporters of the morally corrupt late Republic of the civil wars. The Principate therefore was not the best option, but the only option, the Republican option: what could an anti-Augustan Republican support if not Augustus himself?

\section{Augustus' Ministry of Truth}

I have so far shown how a reading of Kennedy 1992 in the light of totalitarianism takes us to the suggestion that Augustan ideology allowed the 'fiction of a normal world' in which anti-Augustan and pro-Augustan thinking could coexist without discord in the 'doublethink' expressed by the literary texts, at least as long as these did not attempt to propose alternative leaders or realistic political alternatives ${ }^{57}$ However, there is a further aspect of Arendt's totalitarianism which may be recognised as equally applicable to the interpretation of Augustan literary texts, with regard to their tendency to recompose, and therefore 'rewrite,' past Republican history with a teleological drive towards the Augustan regime. Once Republican history is reconfigured in the light of this higher Augustan telos, its particular events can also be 
explained and interpreted according to the wider ideological system, which bears no little resemblance to the ideological system of totalitarian regimes as analysed by Arendt in The Origins.

Arendt's insistence on the uniqueness of totalitarian rule must be inscribed within her belief that the practice of the historians cannot in any way enable us to make future predictions. ${ }^{58}$ Such a conviction is made even more cogent when we read it in direct opposition to what she identifies as itself a practice of totalitarian propaganda and of ideologies in general. For Arendt, totalitarian propaganda is based on 'the assertion that all happenings are scientifically predictable, ${ }^{59}$ and in doing so it develops the totalitarian nature of all ideologies, which 'pretend to be scientific philosophies' ${ }^{\prime 60}$ whose "claim to total explanation promises to explain all historical happenings: the total explanation of the past, the total knowledge of the present, and the reliable prediction of the future. ${ }^{61}$ The role of what she calls the 'rewriters of history' in totalitarian systems - employees of Orwell's 'Ministry of Truth' - involves a rewriting of the past as well as a prediction of the future. Their aim is 'to reveal official history as joke, to demonstrate a sphere of secret influences of which the visible, traceable, and known historical reality is only the outward façade erected explicitly to fool the people'. ${ }^{62}$ This attitude was only possible among an intellectual elite which had become, through the traumatic experience of the first war, already averse to official historiography and believed that history 'was a forgery anyway'. This cynical loss of belief entailed tremendous consequences:

To this aversion of the intellectual elite for official historiography, to its conviction that history, which was a forgery anyway, might as well be the playground of crackpots, must be added the terrible, demoralizing fascination in the possibility that gigantic lies and monstrous falsehoods can eventually be established as unquestioned facts, that man may be free to change his own past at will, and that the difference between truth and falsehood may cease to be objective and become a mere matter of power and cleverness, of pressure and infinite repetition.

(Arendt 2004 [or. 1951]: 441)

According to Arendt, this blind and unscientific belief into the existence of a consistent and wholly explicable system of connections which can explain past, present and future events is the most dangerous method for interpreting and ultimately exploiting history. When scientific historiography dies, the gaps in our historical knowledge end up being filled not by educated and cautious conjectures played off against one another, but by one-sided and unjustified chains of equally unjustified plots. As we shall see more clearly below, these plots are conjectured both by 'the destroyers of history,' and by the subjects themselves, already endowed with the authority to embody their leader, the ideology, and therefore also allowed to fill in the gaps of history by using the same holistic system of connections indirectly suggested by the ideology itself. This gives rise to a maze of conspiracy theories (such as that of the existence of a Jewish world-conspiracy) whose truth is impossible to disqualify from within the system, if not without breaking the whole system of consistency on which the theories themselves have been built up.

This practice of rewriting history is also considered by Arendt a unique modern experience: the ancients, she writes, were merely 'satisfied with a passing victory of the argument at the expense of truth, whereas the moderns want a more lasting victory at the expense of reality'; while 'the old manipulators of logic were the concern of the philosopher... the modern manipulators of facts stand in the way of the historian. ${ }^{63}$ 
Nevertheless, I shall go one more time explicitly against Arendt and suggest that her reflections on the workings of ideologies have significant bearings for our interpretation of Augustan poetry, and especially for our understanding of the 'continental divide' over the interpretation of Virgil's Aeneid.

Let us turn briefly to the use of Republican history in Book 4 of the Aeneid. The episode of Aeneas and Dido, as is well known, includes significant echoes of both midRepublican and late Republican history. On the one hand, it is an aition for the outbreak of the Punic wars, explicitly predicted by Dido in her curse (Aen. 4.621-9) ${ }^{64}$ while the destruction of Carthage is evoked and mapped onto Dido's very death by means of an eloquent simile (Aen. 4.669-71), ${ }^{65}$ and further evocations of the Punic conflict are present at various points in Books 1 and $4 .{ }^{66}$ On the other hand, however, critics have long recognised allusions to the civil/foreign war that ended the Roman Republic in the doubling of the characters of Antony and Cleopatra in the mythical love story between Aeneas and Dido: ${ }^{67}$ both Antony and Aeneas are Roman, or proto-Roman, lovers delayed in the alluring and luxurious court of an oriental queen; both queens commit suicide and are tied to each other by an unmistakable linguistic echo (cf. Dido at Aen. 4.644 pallida morte futura and Cleopatra at Aen. 8.709 pallentem morte futura).

Readers of 'further voices' in the Aeneid, emphasising the sympathetic portrait of Dido, may interpret the comparison between Dido's death and Carthage's destruction as expressing Virgil's anti-imperialistic stance, while optimistic readers could emphasise that Dido's death is the prize to pay for the foundation of Rome - a city that will eventually triumph over its most formidable enemy. Similarly, the momentary juxtaposition with Antony can be seen to undermine the moral stance of protoAugustan Aeneas, or even to suggest interchangeability between Antony and Octavian, since either winner would eventually become (a) Caesar. But at the same time the development of the plot also suggests the opposite: namely that Aeneas/Augustus is no Antony, because if Aeneas had behaved like Antony, Rome would have never been founded.

As we have already noted in the previous section, the simultaneous availability of these options highlights both the polysemy of Virgil's text and the 'doublethink' of the literary and ideological system of which the Aeneid is simultaneously creation and creator. But the text also encourages us readers to fill in the dots and set up connections between the historical events evoked therein. One possible way to reconcile the presence of Punic and civil wars in the Carthage episode is to take both events as unavoidable steps of Republican history: they are the tanta moles necessary for the establishment of the 'Augustan people'. ${ }^{68}$ To this interpretation, we may add that the two events were already associated in literary and historiographical texts other than the Aeneid, and that the Romans perceived, at least since Sallust's so-called 'theorem of metus hostilis,' a very much alive cause-and-effect connection between the destruction of Carthage in $146 \mathrm{BC}$ and the start of the civil wars. ${ }^{69}$ As Sallust puts it in all his extant works, ${ }^{70}$ it was precisely the destruction of Carthage, and the subsequent disappearance of that 'fear of the enemy' which is a necessary element of national unity, that brought about the crisis of the Roman Republic which ultimately resulted in the shedding of brotherly rather than foreign blood. In Augustan literature, this causeand-effect association is often evoked by Horace (and undoubtedly attributed to Asinius Pollio in his Ode 2.1), ${ }^{71}$ and it also surfaces in the mouth of Hannibal in Livy's Book $30 .{ }^{72}$ Thus the Punic wars not only led to the abolition of Rome's arch-enemy but also 
triggered the civil conflict which resulted from that very abolition. The simultaneous evocation of Punic and civil wars in Aeneid 4 may bring light to the cause-and-effect connection between the two events, also possibly presented by Dido in her curse when she ordains not just the Punic wars, but more specifically the wars in Latium and, according to some readers, the civil conflict (Aen. 4.629 pugnent ipsi nepotesque, 'let them and their descendants fight'). ${ }^{73}$

The Sallustian cause-and-effect connection between Punic and civil wars has important repercussions for our interpretation of Virgil's alleged dissent in the Aeneid: it diverts the attention from Augustus' participation in the bloodshed of the civil wars to their characterisation as an undoubtedly gloomy historical event, but caused by the interruption of that foreign military policy that Augustus' Principate celebrates and currently attempts to restore. More importantly, the suggestion inscribed in Sallust's theorem, namely that civil war may return if the citizens do not align with Augustus' foreign military policy on the model of the middle Republic, turns the alleged 'further voice' of dissent into precisely the opposite: a subtle and veiled threat, that kind of ideological terror which is necessarily inscribed in all forms of totalitarian propaganda. The technique employed by Virgil would also suit the use of totalitarian propaganda described by Arendt in The Origins:

The effectiveness of this kind of propaganda demonstrates one of the chief characteristics of modern masses. They do not believe in anything visible, in the reality of their own experience; they do not trust their eyes and ears but only their imaginations, which may be caught by anything that is at once universal and consistent in itself. What convinces masses are not facts, and not even invented facts, but only the consistency of the system of which they are presumably part ... they are predisposed to all ideologies because they explain facts as mere examples of laws and eliminate coincidences by inventing an all-embracing omnipotence which is supposed to be at the root of every accident. Totalitarian propaganda thrives on this escape from reality into fiction, from coincidence into consistency ... Before they seize power and establish a world according to their doctrines, totalitarian movements conjure up a lying world of consistency which is more adequate to the needs of the human mind than reality itself...

(Arendt 2004 [or. 1951]: 452-4)

In other words, totalitarian propaganda does not explicate all reconstructions fully: it creates a consistent system which permeates the masses' way of perceiving reality so much that the individuals are left to draw links for themselves, and in doing so - in becoming active part of the ideological game - they become effectively complicit with the ideology itself.

\section{Conclusion}

Interpreting the Aeneid is a practice that forces us to create and imagine links, and this practice is inextricable from a simultaneous understanding, or reconstruction, of the 'world of consistency' that the Augustan ideology attempted to conjure up. Reading the cause-and-effect connection between Punic and civil wars in the poem means becoming complicit with the practice of interpreting past events according to a totalising interpretation of history which aims at historical scientificity. In this sense, the readers themselves, and not Virgil only, turn into those rewriters - and destroyers - of history who, according to Arendt, created 'gigantic lies and monstrous falsehoods... so that the 
difference between truth and falsehood may cease to be objective and become a mere matter of power and cleverness, of pressure and infinite repetition'. ${ }^{74}$

However, there may be a way to dissent left even when acting from within the system: to highlight the fictionality of the whole construct, and thus to unmask the construct, and the ideology itself, as an artificial forgery. We have already seen how Kennedy 1992, when analysed from this point of view, can be interpreted as an anti-ideological, and therefore anti-Augustan piece. The same, however, may be said of Virgil's Carthage episode, once we notice the emphasis with which this text signposts its own fictionality. Indeed, if Virgil's Aeneid hints at the creation of 'gigantic lies' and 'monstrous falsehoods,' it does so by drawing attention to the rewriting of both myth and history in the space dedicated to truly monstrous Fama (Aen. 4.173-97), in which his and her singing of facta atque infecta (Aen. 4.190) signposts the fictionality of the meeting between Aeneas and Dido, and of the history of Antony and Cleopatra mapped beneath the mythical fiction. ${ }^{75}$ The metapoetic attention given to the metahistorical artificiality of both stories undermines the rumours spread against Antony, and also highlights the fact that the meeting between Aeneas and Dido is based on a chronological impossibility, since 370 years actually passed between the fall of Troy in 1184 BCE and Dido's foundation of Carthage in 814 BCE.

But if Virgil's traumatic experience in the civil wars had caused a nihilistic loss of faith in the reliability of history, as it did with the $20^{\text {th }}$ century intellectuals mentioned by Arendt, then the consciousness that the whole construct is actually based on a lie will eventually lose its importance. Like totalitarian systems, Augustan ideology will also 'demonstrate that action can be based on any hypothesis and that, in the course of consistently guided action, the particular hypothesis will become true, will become actual, factual reality'. ${ }^{76}$

\section{BIBLIOGRAPHY}

Ahl, F. 1976. Lucan: An Introduction. Ithaca.

Arendt, H. 1961. Between Past and Future: Six Exercises in Political Thought. London.

Arendt, H. 2004. The Origins of Totalitarianism, with a new introduction by S. Power. New York. (or. 1951).

Barchiesi, A. 1997. The Poet and the Prince: Ovid and Augustan Discourse. Berkeley and London. Or. 1994. Il poeta e il principe: Ovidio e il discorso augusteo. Roma.

Bertman, S. 2000. “Cleopatra and Antony as Models for Dido and Aeneas.” EMC n. s. 19: 395-98.

Boyle, A. J. 2003. Ovid and the Monuments: A Poet's Rome. Bendigo.

Casali, S. 2006. "The Art of making oneself hated: Rethinking (anti-) Augustanism in Ovid's Ars Amatoria." The Art of love: Bimillennial Essays on Ovid's Ars Amatoria and Remedia Amoris. Eds. R. K. Gibson, S. Green and A. Sharrock. Oxford: 216-34. 
Clément-Tarantino, S. 2006. Fama ou la renommée du genre: recherches sur la représentation de la tradition dans l'Énéide. $\mathrm{PhD}$ thesis. Lille.

Clément-Tarantino, S. 2009. "Phémios dans l'Énéide et les 'libertés' du poète épique." Le poète irrévérencieux. Modèles hellénistiques et réalités romaines. Eds. B. Delignon et Y. Roman. Lyon: 227-242.

Conte, G. B. 1990. “Le troppe voci di Virgilio.” RFIC 118: 490-99.

Davis, P. J. 1999. “Ovid's Amores: a political reading." CP 94: 431-49.

Davis, P. J. 2006. Ovid and Augustus: a political reading of Ovid's erotic poems. London.

DuQuesnay, I. M. Le M. 1984. "Horace and Maecenas: The Propaganda Value of Sermones 1." Poetry and Politics in the Age of Augustus. Eds. T. Woodman and D. West. Cambridge: 19-58.

Edgeworth, R. J. 1976-77. “The Death of Dido.” CJ 72: 129-33.

Elsner, J. 1991. "Cult and Sculpture: Sacrifice in the Ara Pacis Augustae." JRS 81: 50-61.

Forti, S. 2001. Il Totalitarismo. Bari.

Gale, M. R. 1997. "Propertius 2.7: Militia Amoris and the Ironies of Elegy." JRS 87: 77-91.

Galinsky, K. 1996. Augustan Culture: An Interpretive Introduction. Princeton.

Giusti, E. 2014. The Enemy on Stage: Augustan Revisionism and the Punic Wars in Virgil's Aeneid.

Cambridge PhD diss.

Giusti, E. 2016. "My Enemy's Enemy is my Enemy: Virgil's illogical use of Metus Hostilis." Augustan Poetry and the Irrational. Ed. P. Hardie. Oxford: 37-55.

Goldschmidt, N. 2013. Shaggy Crowns: Ennius' Annales and Virgil's Aeneid. Oxford.

Goldschmidt, N. Forthcoming. "Textual Monuments: Reconstructing Carthage in Augustan Literary Culture" CP special issue on Carthage and Rome. Ed. D. Feeney.

Gowing, A. 2005 Empire and Memory: The Representation of the Roman Republic in Imperial Culture. Cambridge.

Gruen, E. S. 1985. “Augustus and the Ideology of War and Peace.” The Age of Augustus. Ed. R. Winkes. Providence and Louvain: 51-72.

Habinek, T. N. 1998. The Politics of Latin Literature: Writing, Identity, and Empire in Ancient Rome. Princeton.

Habinek, T. N. 2002. "Ovid and Empire" in The Cambridge Companion to Ovid. Ed. P. Hardie. Cambridge: $46-61$.

Hardie, P. R. 1986. Virgil's Aeneid: Cosmos and Imperium. Oxford.

Hardie, P. R. 1993. The Epic Successors of Virgil, Cambridge.

Hardie, P. R. 1997. "Questions of authority: the invention of tradition in Ovid Metamorphoses 15." The Roman Cultural Revolution. Eds. T. N. Habinek and A. Schiesaro. Cambridge: 182-98.

Hardie, P. R. 2006. “Virgil's Ptolemaic Relations”. JRS 96: 25-41.

Hardie, P. R. 2009 “Virgil: a Paradoxical Poet?" Paradox and the Marvellous in Augustan Literature and Culture. Ed. P. Hardie. Oxford: 95-112.

Hardie, P. R. 2012. Rumour and Renown. Representations of Fama in Western Literature. Cambridge. 
Heinze, R. 1993. Virgil's Epic Technique, transl. of 3rd edition (1915) by H. and D. Harvey and F. Robertson. Bristol.

Henderson, J. 1987. “Lucan/The Word at War.” Ramus 16: 122-64.

Henderson, J. 1998. “Review: Exemploque Suo Mores Reget.” Hermathena 164: 101-116.

Huskey, S. J. 2008. Review of P. J. Davis 2006. CJ 103: 335-7.

Johnson, W. R. 1976. Darkness Visible: A Study of Vergil's Aeneid. Berkeley and London.

Kennedy, D. F. 1992. ““'Augustan” and “Anti-Augustan”: Reflections on Terms of Reference.” Roman Poetry and Propaganda in the Age of Augustus. Ed. A. Powell. London: 26-58.

Kennedy, D. F. 1994. Review of White 1993. G\&R 41: 228-9.

Kennedy, D. F. 2013. Antiquity and the Meanings of Time: A Philosophy of Ancient and Modern Literature. London.

Knox, P. E. 2004. "The Poet and the Second Prince: Ovid in the Age of Tiberius." MAAR 49, 1-20.

Le Doze, P. 2014. Le Parnasse face à l'Olympe: Poésie et culture politique à l'époque d'Octavien/Auguste, Roma.

Lyne, R. O. A. M. 1987. Further Voices in Vergil's Aeneid. Oxford.

Martindale, C. 1993. "Descent into Hell. Reading Ambiguity, or Virgil and the Critics" PVS 21:

111-50. Reprinted in Virgil: Critical Assessments of Classical Authors. Volume III: The Aeneid. Ed. P. Hardie. London and New York: 14-48.

Mineo, B. 2011. "Principal Literary Sources for the Punic Wars (apart from Polybius)." A Companion to the Punic Wars. Ed. D. Hoyos. Oxford: 111-27.

Morgan, L. 1998. “Assimilation and Civil War: Hercules and Cacus.” Vergil's Aeneid. Augustan Epic and Political Context. Ed. H.-P. Stahl. Swansea: 175-97.

Morgan, L. 1999. Patterns of Redemption in Virgil's 'Georgics'. Cambridge.

Nau, F. 2007. Review of P. J. Davis 2006. BMCR: http://bmcr.brynmawr.edu/2007/2007-06-43.html O'Gorman, E. 1997. "Love and the Family: Augustus and the Ovidian Legacy.” Arethusa 30: 103-24. Orwell, G. 1949. Nineteen Eighty-Four: a Novel. London.

Parry, A. 1963. “The Two Voices of Virgil's Aeneid.” Arion 2: 66-80.

Recalcati, M. (ed.) 2007. Forme contemporanee del totalitarismo. Torino.

Reeve, M. 1987. “The Future in the Past.” Homo Viator. Classical Essays for John Bramble. Eds. M. Whitby, P. Hardie and M. Whitby. Bristol: 319-22.

Seager, R. 1980. "Neu sinas Medos equitare inultos: Horace, the Parthians and Augustan foreign policy.” Athenaeum 58: 103-18.

Sharrock, A. R. 1994. "Ovid and the Politics of Reading." MD 33: 97-122.

Shi, V. S.-R. and Morgan, L. 2015. “A Tale of Two Carthages: History and Allusive Topography in Virgil's Libyan Harbor (Aen. 1.159-69).” TAPA 145: 107-33.

Syed, Y. 2005. Vergil's Aeneid and the Roman Self: Subject and Nation in Literary Discourse. Ann Arbor. Syme, R. 1939. The Roman Revolution. Oxford and New York.

Thomas, R. F. 2000. “A Trope by any other name: "Polysemy,” Ambiguity, and Significatio in Virgil." 
HSCP 100: 381-407.

Thomas, R. F. 2001. Virgil and the Augustan Reception. Cambridge.

White, P. 1993. Promised Verse: Poets in the Society of Augustan Rome. Cambridge Mass.

Zanker, P. 1988. The Power of Images in the Age of Augustus, transl. A. Saphiro, Ann Arbor.

Ziogas, I. 2015. "The Poet as Prince: Author and Authority Under Augustus." The Art of Veiled Speech: Self-Censorship from Aristophanes to Hobbes. Eds. H. Baltussen and P. J. Davis. Philadelphia: 115-36.

Žižek, S. 2011. Did Somebody Say Totalitarianism? Five Interventions in the (Mis)Use of a Notion. London.

\section{NOTES}

1. Barchiesi 1997: 6 n.1: 'I am convinced that the field has more of a future than Kennedy himself allows us to foresee, precisely thanks to generous contributions like the one he offers' (cited from the translated edition; originally 1994).

2. Impatience and dissatisfaction at the debate were already in the air on the European side as Kennedy wrote; Hardie 1993: 2 speaks of it as 'monotonous' and 'reductive'.

3. From Parry's 'two voices' of the Aeneid (Parry 1963), the formulation 'further voices' was introduced by Lyne 1987, and soon challenged by Conte's 'too many voices' (Conte 1990).

4. Kennedy 1992: 40.

5. Kennedy 1992: 42.

6. Kennedy 1992: 46.

7. Kennedy 1992: 40: 'The dominated voice may not be heard, but is not absent; the potentiality for subversion is inscribed in every use of every word. Thus it is that discourse, as well as being an instrument and effect of power, is at the same time a focus for resistance and subversion. Establishment discourse is shaped by and contains traces of its opposition (and vice versa), even if the conflicting voice is not heard in its own right.'

8. A point made by Ziogas 2015: 130.

9. Martindale 1993: 31; Thomas 2001: 25-6.

10. Already since Gale 1997, a very influential reading of the Augustanism and anti-Augustanism of Propertius in the light of Kennedy 1992.

11. Sharrock 1994: 98.

12. Sharrock 1994: 98.

13. Sharrock 1994: 122: 'while I read Ovid in such a way as to undermine Augustan authority staked on the moral legislation, I necessarily accord that authority and so in a sense legitimize it.'

14. Sharrock 1994: 106-9.

15. Barchiesi 1997: 175-6, in explicit opposition to Kennedy 1992.

16. Casali 2006; Boyle 2003: 9 n.22; Davis 1999 and 2006.

17. O'Gorman 1997: 104-5.

18. Hardie 1997: 182.

19. Barchiesi 1997: 84, 272.

20. Habinek 2002: 61, with reference to Galinsky 1996. Cf. also Habinek 1998: 6, 167.

21. pace Huskey 2008; I agree better with Nau 2007.

22. Davis 2006: 10.

23. Davis 2006: 14.

24. Davis 2006: 15.

25. Davis 2006: 15-16. 
26. Kennedy 1992: 40, cited above.

27. Gruen 1985: 54 .

28. Gruen 1985: 62 .

29. Cf. the use of Nineteen Eighty-Four in Kennedy 2013, especially pp. 76-83.

30. At least since Henderson 1987.

31. Kennedy 1992: 35 (my emphasis).

32. Kennedy 1992: 31 (on which see also DuQuesnay 1984); a passage instead interpreted by Galinsky 1996: 57 as signposting symbiosis of intents between Horace and Augustus.

33. Kennedy 1992: 45.

34. Galinsky 1996: 57 and 228.

35. Davis 2006: 130 n.4 attributes to Galinsky a '(superficially) similar view' to Kennedy.

36. See n.20.

37. Henderson 1998: 111

38. The question is intertwined to the degree of anachronistic analysis in Syme 1939; see Le Doze 2014: 19-38 with bibliography. Note that Zanker 1988 remains still today an unavoidable point of departure for our understanding of Augustan 'propaganda'.

39. See White 1993 for a reassessment of the issues of patronage and clientelism in Augustan Rome, with the critique of Kennedy himself regarding White's insistence on apolitical amicitia and downplay of its power relations: 'ideologically nothing washes whiter than White. I think I'll have my old powder back, please' (Kennedy 1994: 229).

40. Žižek 2011: 3.

41. See for example Recalcati 2007.

42. The term totalitarismo first appears in connection to Italian fascism in a 1923 article by Giovanni Amendola; on the history of totalitarianism, see Forti 2001.

43. Arendt 2004: 14-15.

44. Arendt 2004: 170.

45. Arendt 2004: 525.

46. In Arendt 1961: 91-142.

47. Arendt 1961: 98.

48. Arendt 1961: 104, 25.

49. Arendt 1961: 124.

50. Arendt 1961: 99.

51. Gowing 2005: 20-1 speaks of 'a new ideology, one that has co-opted the moral value of traditional Republican exempla in order to affirm the supremacy of a single authority... historical allusion apart from the emperor has become increasingly difficult to achieve.'

52. Kennedy 1992: 40, quoted above.

53. On the debate see especially Hardie 2009, Thomas 2001: 1-14 (based on Thomas 2000), Martindale 1993.

54. Orwell 1949 chapter 9.

55. See as seminal studies Parry 1963, Johnson 1976, Lyne 1987.

56. See Morgan 1998 and 1999 for the idea of civil war as 'constructive destruction'.

57. The situation can be seen to change, for instance, with Ovid's alleged anti-Tiberianism which is only made possible by his favouring of Germanicus: see Knox 2004.

58. Arendt 2004: 165: '...no matter how much we may be capable of learning from the past, it will not enable us to know the future.'

59. Arendt 2004: 500.

60. Arendt 2004: 604.

61. Arendt 2004: 606.

62. Arendt 2004: 441.

63. Arendt 2004: 18-19. 
64. The reference to Hannibal in Dido's curse (Aen. 4.625 exoriare aliquis nostris ex ossibus ultor) is oblique but appeared certain to commentators at least since Servius (ad 4.625 "et ostendit Hannibalem").

65. There is also a clear connection between the death of Dido, the first woman of Carthage, and the death of Hasdrubal's wife, the last woman of the city, who similarly kills herself on a pyre, in the temple of Eshmoun (App. Pun. 131; Liv. Per. 51), see Edgeworth 1976-7.

66. I discuss these in Giusti 2014, but see already Goldschmidt 2013: 109-15 and Forthcoming; Shi and Morgan 2015.

67. See especially Bertman 2000; Syed 2005: 184-93; Hardie 2006 and 2014: 55-57.

68. Reference is of course to Aen. 1.33 tantae molis erat Romanam condere gentem.

69. On metus hostilis in Virgil's Carthage episode see Giusti 2016.

70. Sall. BJ 41.2; BC 10.1-2; Hist. fr. 1.11 McGushin.

71. On the dead of the civil wars becoming offerings to the Carthaginian and African manes see Hor. C. 2.1.25-8, but also Lucan 1.39 Poeni saturentur sanguine manes and 4.789-90: ferat ista cruentus / Hannibal et Poeni tam dira piacula manes, with discussion in Ahl 1976: 82-115. On metus hostilis in Horace see especially Epode 7 and Epode 16; cf. Seager 1980 for Horace's use the Parthian menace in order to avoid civil discord.

72. See Liv. 30.44.7-8 with Reeve 1987. This is the only passage where Livy suscribes to Sallust's theory, which must have received full treatment in the account of the debate between Scipio Nasica and Cato on the destruction of Carthage, according to the Periocha of Book 49. See Mineo 2011: 123.

73. The passage is taken as alluding to civil war already since Servius, ad Aen. 4.629; see Reeve 1987 for a persuasive defense of Servius' interpretation.

74. Arendt 2004: 441, quoted above.

75. Virgil's Fama has often been singled out as standing for the poem as a whole, highlighting its inconsistencies, and parading its fictionality. See especially Hardie 1986: 273-80 and 2012: 79-112, Clément-Tarantino 2006 and 2009, Syson 2013: 44-62.

76. Arendt 1961: 87.

\section{ABSTRACTS}

The allegedly old-fashioned debate over the pro- or anti- Augustanism of Augustan texts was superseded in 1992 by Duncan Kennedy's 'reflections' over these terms of reference. Since then, the old dichotomy has appeared to be useless in a dialectic which is always bound to hold Augustus as the unavoidable point of reference. And yet scholarship continues to be divided over the interpretation of Augustus' rule and its visible or invisible effects on the poetry produced under his patronage. The present article revisits Kennedy's influential essay and its reception, arguing that it offers further reflections on the workings of Augustan ideology than it has so far been assumed. Moreover, while the nature of Augustus' rule is still a point of heated debate, the present article argues that a combined reading of Kennedy 1992 and Hannah Arendt's writings over the ideological language of totalitarian systems may open new possibilities for our interpretation the Augustan regime and the anti-Augustanism of the Augustan texts. 
INDEX

Keywords: Augustus, Augustan Literature, Virgil, Aeneid, Ovid, Harvard School of Virgilian Studies, European School of Virgilian Studies, Totalitarianism, Ideology, Duncan Kennedy, Hannah Arendt, George Orwell

\section{AUTHOR}

\section{ELENA GIUSTI}

St John's College Cambridge 